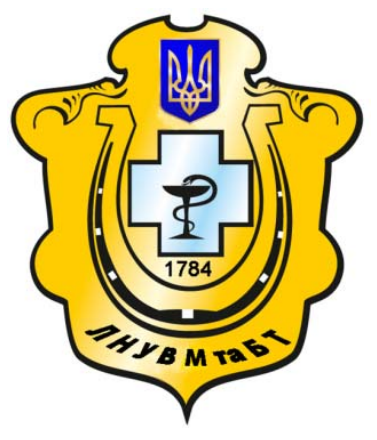

Науковий вісник Львівського національного університету ветеринарної медицини та біотехнологій імені С.З. Гжицького

Scientific Messenger of Lviv National University of Veterinary Medicine and Biotechnologies named after S.Z. Gzhytskyj

doi:10.15421/nvlvet7517

ISSN 2519-268X print

ISSN 2518-1327 online

http://nvlvet.com.ua/

УДК:637.514.034:66.021.4

\title{
Компоненти теплообміну під час вільноконвективного охолодження моделі напівтуші
}

\author{
О.А. Чернюшок ${ }^{1}$, В.Г. Федоров ${ }^{2}$, О.І. Кепко ${ }^{2}$ \\ olgachernyushok@list.ru \\ ${ }^{1}$ Національний університет харчових технологій, \\ вул. Володимирська, 68, Київ, 01601, Україна; \\ ${ }^{2}$ Уманський національний університет садівництва, \\ вул. Інститутська, 1, м. Умань, 20300, Украӥна
}

\begin{abstract}
Стаття присвячена проблемі зберігання м'ясної сировини. Відомо, ще під час тривалого зберігання в м'ясі відбуваються зміни, які зумовлені його властивостями, умовами та термінами зберігання. Ці зміни призводять до втрат маси та якості продукиії: відбувається зміна кольору м'язової тканини - в результаті зміни концентрації міоглобіну в поверхневому шарі (внаслідок випаровування вологи) і утворення метміоглобіну.

Проблема зменшення втрат сировини та збереження якості має важливе значення в технології виготовлення м'ясних продуктів. В статті представлені дослідження щодо визначення інтенсивності процесів охолодження м'ясних моделей, що залежать від розмірів продукту, температури та швидкості повітря.

В охолоджених м'ясних продуктах швидкість перебігу процесів, що впливають на якість, у багато разів менша. В статті досліджено динаміку густини теплового потоку під час холодильного оброблення зразків м'ясних продуктів.

Доведено, шо перенесення енергії за рахунок випромінювання не впливає на усихання м'яса. Таким чином, збільшення частки теплового потоку за рахунок випромінювання може сприяти зменшенню часу охолодження.

Встановлено, щзо швидке охолодження м'яса забезпечує добрий товарний вигляд, тонку та стійку плівку підсихання, щуо сприяс подовженому терміну зберігання м'ясних продуктів.

Ключові слова: вільноконвективне охолодження, м'ясо, модель напівтуші, параметри, температура, усихання продукту, теплообмін.
\end{abstract}

\section{Компоненты теплообмена при свободноконвективном охлаждении модели полутуши}

\author{
О.А. Чернюшок ${ }^{1}$ В.Г. Федоров ${ }^{2}$ О.И. Кепко ${ }^{2}$ \\ olgachernyushok@list.ru \\ ${ }^{1}$ Национальный университет пищевых технологий, \\ ул. Владимирская, 68, г. Киев, 01601, Украина;

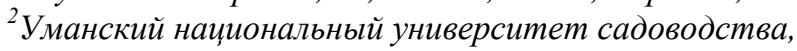 \\ ул. Институтская, 1, г. Умань, 20300, Украина
}

Статья посвящена проблеме хранения мясного сырья. Известно, что во время длительного хранения в мясе происходят изменения, обусловленные его свойствами, условиями и сроками хранения. Эти изменения приводят к потерям массы и качества продукции: происходит изменение ивета мышечной ткани - в результате изменения концентрации миоглобина в поверхностном слое (вследствие испарения влаги) и образование метмиоглобина.

Citation:

Chernyushok, O.A., Fedorov, V.G., Kepko, O.I. (2017). Components heat exchange during free convective cooling carcasses model. Scientific Messenger LNUVMBT named after S.Z. Gzhytskyj, 19(75), 85-88. 
Сокрашение потерь сырья и сохранения качества имеет важное значение в технологии изготовления мясных продуктов. В статье представлены исследования по определению интенсивности процессов охлаждения мясных моделей, которые зависят от размеров продукта, температуры и скорости воздуха.

В охлажденных мясных продуктах скорость протекания прочессов, влияюших на качество, во много раз меньше. В статье исследована динамика плотности теплового потока во время холодильной обработки образцов мясных продуктов.

Доказано, что перенос энергии за счет излучения не влияет на усушку мяса. Таким образом, увеличение доли теплового потока за счет излучения может способствовать уменьшению времени охлаждения.

Установлено, что быстрое охлаждение мяса обеспечивает хороший товарный вид, тонкую и устойчивую пленку подсыхания, что способствует продлению срока хранения мясных продуктов.

Ключевые слова: свободноконвективное охлаждение, мясо, модель полутуши, параметры, температура, усушка продукта, теплообмен.

\title{
Components heat exchange during free convective cooling carcasses model
}

\author{
O.A. Chernyushok ${ }^{1}$, V.G. Fedorov ${ }^{2}$, O.I. Kepko ${ }^{2}$ \\ olgachernyushok@list.ru \\ National University of Food Technology, \\ Volodymyrska Str, 68, Kyiv, 01601, Ukraine; \\ Uman National University of Horticulture, \\ Instytutska Str. 1, Uman, 20300, Ukraine
}

The article is dedicated to the aspects of meat raw materials preservation. It is known that during the long meat preservation, different changes are taking place. These changes are subject to meat peculiarities, term and time of preservation. They lead to a meat mass reduction and product quality deterioration: muscles tissue changes its color because of myoglobine concentration change in the upper layer (as a result of moisture evaporation) and formation of metmyoglobin.

Problem of raw material loss reduction and quality preservation is very important in meat products technology. The article presents a research for determination of intensity of meat cooling models, which depends on product size, temperature and air velocity.

Speed of the processes that impacts the quality of the meat is significantly lower in the cooled products. The subject of the article is a research of dynamic of the density of heat flow during the cooling of meat samples.

It is proved that the energy transfer due to emission does not affect meat shrinkage. Therefore, increase of heat flow share due to emission could improve the cooling time.

It is determined that the speedy cooling process of meat provides its good marketable conditions, persistent film of predrying that improves terms of meat products preservation.

Key words: free convective cooling meat carcasses model parameters, temperature, shrinkage product heat.

\section{Вступ}

Охолоджені м'ясні продукти все більше користуються попитом серед вимогливих споживачів. Саме вони відносяться до числа харчових продуктів, що швидко псуються, оскільки тривале їх зберігання в звичайних умовах без спеціальної обробки неможливо.

Поряд 3 різними методами консервування харчових продуктів, що швидко псуються, в даний час найбільш ефективними є методи холодильної обробки та зберігання. Застосування методів холодильної технології при обробці м'ясних продуктів, на відміну від інших способів консервування, надає значно менший вплив на природні смакові та органолептичні властивості м'ясних продуктів.

Основними завданнями розвитку холодильної галузі в даний час $є$ : відродження та розвиток вітчизняного конкурентоспроможного холодильного машинобудування; удосконалення технологій холодильного оброблення та зберігання харчової продукції; підвищення енергетичної ефективності холодильних систем і виробництв, що використовують штучний холод.

Саме ці напрямки можуть доповнюватися може змінюватися їх місце серед пріоритетів, але вони актуальні і в даний час.
Охолодження яловичих i свинячих напівтуш в Україні в основному проводять за допомогою охолодженого повітря, технологічні параметри якого швидкість і температуру підтримують постійними або змінюють за тією чи іншою програмою з метою зменшити час охолодження та усихання продукту (Maslikov and Mezentsev, 2004).

Рішення проблем ресурсо- та енергозбереження під час охолодження крупногабаритних м'ясопродуктів грунтується нестачею надійної інформації щодо залежності інтенсивності тепловідведення та усихання сировини від технологічних параметрів повітря та інших факторів. Ці питання досить детально розглянуті в роботі (Zheliba et al., 2008). Проектноконструкторські та наукові розробки минулого сторіччя 3 підвищенням ефективності холодильної обробки м'ясопродуктів здебільшого залишилися без впровадження у виробництво, оскільки змінилися критерії оптимізації та ефективності як загалом, так і для кожного виробника.

\section{Матеріали і методи досліджень}

Об'єктом досліджень виступали процеси охолодження моделей напівтуш. Предмет досліджень: моделі напівтуші м'ясної сировини. Істотне значення результатів розробок оптимізації та ефективності охолодження має застосування під час досліджень 
методів тепломасометрії (Chernyushok et al., 2016). Для створення рекомендацій 3 оптимальних умов традиційних і нових методів охолодження яловичих напівтуш було проведено експериментальні планові дослідження в лабораторних умовах (Anistratenko and Fedorov, 1993). За фізичну модель напівтуші був зразок, вирізаний зі стегна яловичої напівтуші та тепловологоізольваний з усіх боків, крім поверхні з поверхневою плівкою. Як критерії оптимізації було обрано два параметри - середня густина потоку маси з поверхні продукту за час його обробки та енергетичний або техніко-економічний параметр. Останній складався 3 трьох безрозмірних доданків, що враховували витрати на амортизацію і ремонт, на прокачування та охолодження повітря, на охолодження напівтуш (з урахуванням зовнішніх теплоприпливів). Температуру, швидкість та відносну вологість охолодженого повітря в кожному досліді підтримували на постійному рівні. Було проведено повнофакторний експеримент.

\section{Результати та їх обговорення}

Для першого критерію мінімальне значення усихання м'яса мало місце за швидкості $\mathrm{W}_{\text {опт }}=1,56 \mathrm{~m} / \mathrm{c}$ i температури повітря $\mathrm{t}_{\text {опт }}=5,2^{\circ} \mathrm{C}$, для другого техно- економічні витрати були мінімальними, відповідно за умов оптимальної швидкості $\mathrm{W}_{\text {опт }}=1,66 \mathrm{~m} / \mathrm{c}$ та $\mathrm{t}_{\text {опт }}=-$ $3,9^{\circ} \mathrm{C}$.

Було розроблено також рекомендації для здійснення поточних методів охолодження: початкові швидкості $3 . .3,5$ м/с, температури $-4 \ldots-6{ }^{\circ} \mathrm{C}$, $з$ подальшою повільною зміною цих величин до $0,2 \mathrm{~m} / \mathrm{c}$ та $0{ }^{\circ} \mathrm{C}$.

Для сучасних умов циклічної холодильної обробки м'яса безумовний інтерес становить інформація щодо динаміки компонентів тепломасообміну за умов вільної конвекції повітря.

Експериментальним шляхом досліджували зміну всіх складових густини теплового потоку та потоку маси, що випаровується з поверхні моделі напівтуші за умов вільної конвекції та ступінчастого змінення температури повітря $t_{п}$.

За модель напівтуші був циліндр діаметром 8 см та вистою 10 см, що вирізали зі стегна яловичої напівтуші та вставленого до посудини Дьюара так, щоб тепломасообмін відбувався лише 3 поверхні м'яса, вкритої поверхневою плівкою (рис. 1). Ця поверхня розташовувалася в рівень 3 краями посудини, таким чином утворювався одновимірний тепломасообмін, що відповідає тепломасообміну 3 найбільш товстої частини стегна (Cherniushok et al., 2016).

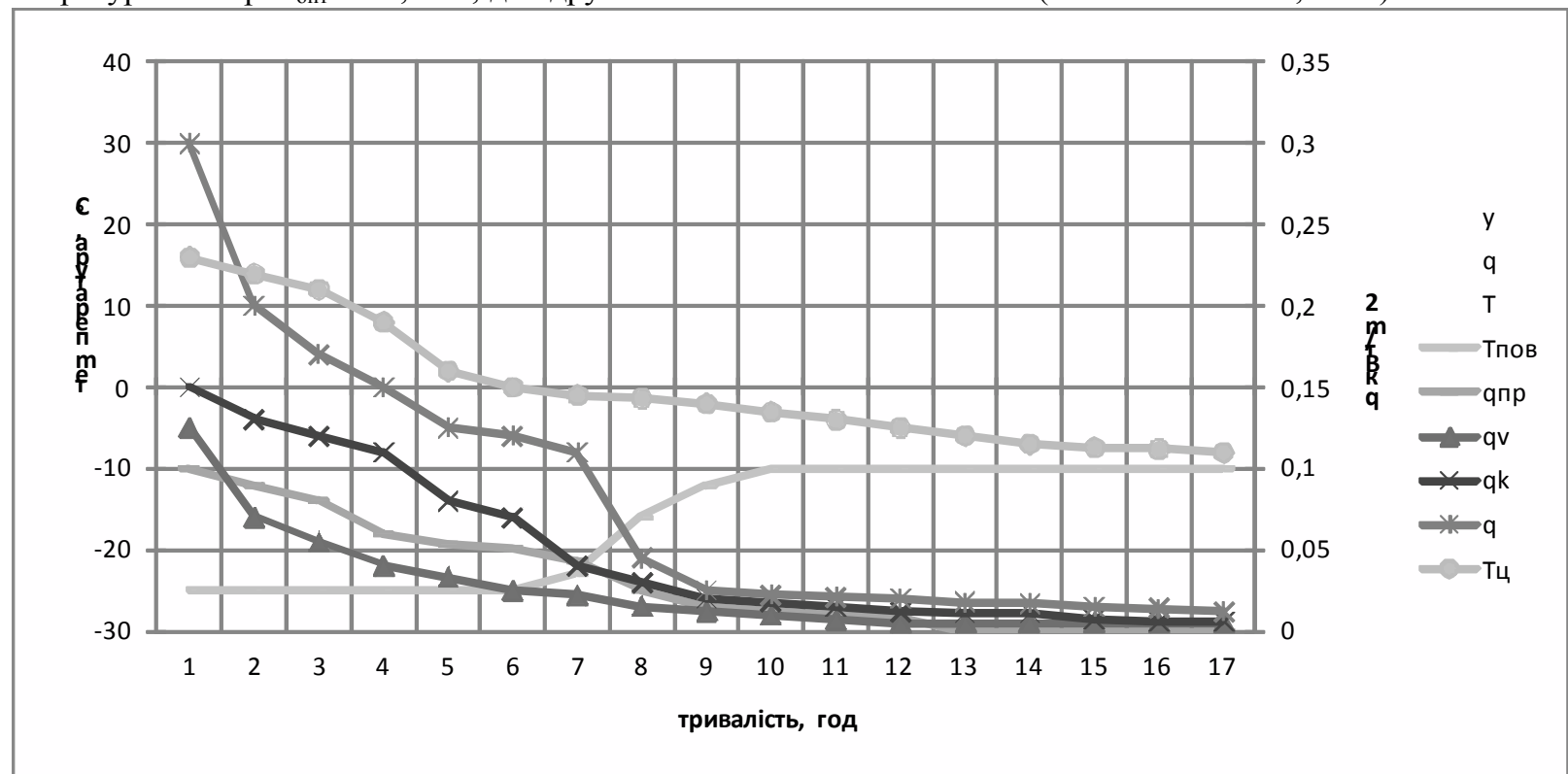

Рис. 1. Динаміка компонентів густини теплового потоку з поверхні м'яса

Для дослідження динаміки всіх компонентів густини теплового потоку з поверхні м'яса: конвективного $\mathrm{q}_{\mathrm{k}}$, променистого $\mathrm{q}_{\text {пр }}$ i масообмінного (разом 3 парою $з$ поверхні) $\mathrm{q}_{\mathrm{s}}$, а також густини потоку маси Тц використовували однакові перфоровані тепломіри діаметром 10 мм і товщиною 1 мм. За допомогою гострого ножа поверхневу плівку товщиною 0,5 мм підрізали для кожного тепломіра так, щоби можна було його цілком закласти до утворюваної порожнини по ізотермі. Під час охолодження плівка дещо скорочувалася, отже щільно прилягала до датчиків.

Ділянка плівки проти першого датчика вкривалася тонкою поліетиленовою плівкою, проти другого тонкою фольгою $з$ малим ступенем чорноти. Таким чином перший тепломір реагував на «сухий» тепловий потік, сигнал другого був меншим, оскільки променистий теплообмін на ділянці із фольгою є слабшим. Нарешті, сигнал третього тепломіра відповідав сумарному значенню густини теплового потоку.

Наявність на поверхні зразка кружків плівки та фольги не впливала на однозначність цих зв'язків. Спеціальними дослідами було доведено, що коефіцієнти «сухої» тепловіддачі з «сухої» поверхні та 3 поверхні, з якої відбувається випаровування, є однаковими із кореляцією, що відрізняється від одиниці не більше як на 0,003 (Fedorov and Dyakusha, 1980).

Метрологічне дослідження того, як треба обчислити тепловий потік за рахунок випаровування вологи 3 
поверхні продукту - чи включати до нього ентальпію води, що перетворилася на пару, або теплоту перегріву пари, що перейшла до повітря - показало, що найправильніше враховувати лише теплоту пароутворення.

Аналітичним та експериментальним шляхом було доведено, що між сигналами тепломірів та компонентами тепломасообміну існує однозначний зв'язок, за умов даних дослідів.

Густина теплового потоку з поверхні за рахунок променевого, конвективного та масообмінного відведення теплоти; ступінь чорноти поверхні зразка та відповідних тепломірів; $\mathrm{T}_{\text {пл }}, \mathrm{T}_{\text {пов }}$ температури поверхні плівки зразка та повітря R-сумарний термічний опір тепломіра та плівки над ними.

Густину потоку маси перевіряли шляхом порівняння інтеграла зважування зразків до та після завершення охолодження. До температура в центрі $\mathrm{t}_{\text {ц }}=$ $+4{ }^{\circ} \mathrm{C}$. Максимальна розбіжність складала $65 \%$, що iï можна вважати задовільною, оскільки податкові похибки виникнення під час визначння поверхні випаровування зразка, за рахунок можливого впливу струмозаломлення провідників та складності і планометричного інтегрування.

Динаміку складових тепломасообміну під час охолодження зразка яловичини із $23{ }^{\circ} \mathrm{C}$ до $+4{ }^{\circ} \mathrm{C}$ в центрі моделі за умов плавного змінення $\mathrm{t}_{\text {пов }} 3-12{ }^{\circ} \mathrm{C}$ до $0{ }^{\circ} \mathrm{C}$ тривало від шостої до десятої години, протягом чотирьох годин.

До початку підвищення температури повітря усі три компонента теплового потоку мали одинаковий порядок (початкові визначення $\mathrm{q}_{\text {пр }}=0,13: \mathrm{q}_{\mathrm{k}}=0,15$ : $\mathrm{q}_{\mathrm{m}}=0,1 \kappa \mathrm{BT} / \mathrm{m}^{2}$. Відомо 3 різних джерел, що за умов примусового руху охолоджуваного повітря початкові

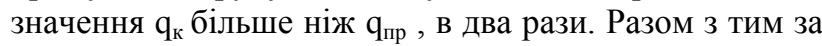
інформацією авторів (Chumak et al., 1982) тепловий потік за рахунок випромінювання може складати $0,435 \mathrm{BT} / \mathrm{m}^{2}$ при $\mathrm{t}_{\text {пл }}=27^{\circ} \mathrm{C}$ та $0,286 \mathrm{BT} / \mathrm{m}^{2}$ при $\mathrm{t}_{\text {пл }}=0{ }^{\circ} \mathrm{C}$. Дуже важливим $€$ факт, що перенесення енергії за рахунок випромінювання не пов'язаний з перенесенням маси, отже не впливає на усихання м'яса. Таким чином, збільшення частки теплового потоку за рахунок випромінювання може бути серйозним фактором в процесі скорочення часу охолодження.

Відомо, що швидке охолодження м'яса забезпечує добрий товарний вигляд, тонку та стійку плівку підсихання, такий вихід соку після розбирання туші та зниження усушки, мале обсіменіння поверхні м'яса, сприяє подовженому терміну зберігання. Разом з тим, швидке та особливо надлишкове охолодження викликає змінення спрямованості біохімічних процесів в м'ясі, що призводить до холодильного стискання, зусилля різання м'яса може бути вдвічі більше ніж після повільного охолодження, отримало органолеп- тичну оцінку 4,33, швидкого та надшвидкого відповідно 3,66 та 2,96 бала. Холодне скорочення яловичини виникає, якщо температура м'яса дана нижчою за $11^{\circ} \mathrm{C}$ раніше, ніж рН стала нижче за 6,2 .

\section{Висновки}

Істотним джерелом енегро- та ресурсозбереження під час охолодження напівтуш та інших крупногабаритних м'ясопродуктів $є$ збільшення теплообміну шляхом удосконалення камер 3 прямим взаємним «контактом» поверхні продукту та випарника. Така схема охолодження може виявитися оптимальною для розвитку способів охолодження за рахунок відсутності повітряних охолоджувачів, вентиляторів та повітропроводів.

\section{Бібліографічні посилання}

Maslikov, M.M., Mezentsev, M.V. (2004). Optimizatsiyne modelyuvannya protsesu zberigannya m'yasa. Harchova promislovist. 3, 150-151 (in Ukrainian).

Zheliba, Yu.O., Harchenko, S.V., OnIschenko, M.V. (2008). Matematichne modelyuvannya harakteristik protsesIv oholodzhennya svinini $\mathrm{u}$ napIvtushah. Holodilna tehnika i tehnologiya. 6(116), 46-51 (in Ukrainian).

Chernyushok, O.A., Fedorov, V.G., Kepko, O.I. (2016). Intensivnist kriogennoyi obrobki myasoproduktiv. Progresivni tehnika ta tehnologiyi harchovih virobnitstv restorannogo gospodarstva ta torgivli. Harkiv. 1(23), 193- 201 (in Ukrainian).

Anistratenko, V.O., Fedorov, V.H. (1993). Matymatychne planuvannia eksperymentiv $\mathrm{V}$ APK. K.: Vyshcha shkola (in Ukrainian).

Cherniushok, O.A., Fedorov, V.H., Kepko, O.I. (2016). Intensyfikatsiia kholodylnoho obroblennia dribnoshmatkovykh miasoproduktiv. Naukovyi visnyk Lvivskoho natsionalnoho universytetu veterynarnoi medytsyny im. S.3. Hzhytskoho. 18, 1(65), 161-165 (in Ukrainian).

Fedorov, V.G., Dyakusha, L.V. (1980). O Vliyanii ispareniya na teplootdachi pri svobodnoy konvektsii. Promishlennaya teplotehnika. 2(4), 58-61 (in Russian).

Fedorov, V.H. (1987). Osnovy teplomasometrii. K.: vyshcha shkola (in Russian).

Chumak, N.G., Chepurenko, V.P., Chuklin, S.G. (1982). Holodilnyie ustanovki. Legkaya i pischevaya promishlennost (in Russian).

Стаття надійшла до редакиї 8.02.2017 